\title{
Physicochemical and microbiological study of "shmen", a traditional butter made from camel milk in the Sahara (Algeria): isolation and identification of lactic acid bacteria and yeasts
}

\author{
By Kacem Mourad*, and Karam Nour-Eddine
}

\author{
Laboratoire de Biologie des Microorganismes et Biotechnologie, Faculté des Sciences, \\ Département de Biotechnologie, Université d'Es Senia \\ BP 1524 Oran El M'Naour (31000) Oran Algérie \\ *Correspondence to: Kacem Mourad, B.P. 8053 SIDI EI-BACHIR, 31026, Oran, Algérie. \\ E-mail: mourad.kacem1@ caramail.com
}

\section{RESUMEN}

Estudio fisicoquímico y microbiológico del "shmen", una mantequilla tradicional del Sahara argelino hecha a partir de leche de camella: aislamiento e identificación de bacterias acido lácticas y levaduras.

Se aislaron los microorganismos (bacterias aeróbicas, coliformes, bacterias acido lácticas, bacterias lipolíticas y levaduras) de 20 muestras de "shmen", una matequilla tradicional del Sahara argelino hecha a partir de leche de camella. Los valores de $\mathrm{pH}$, acidez, libre, Nacl, solidos totales, humedad y grasa oscilaron entre $3,11-4,97,0,19$ $0,36 \%, 1.04-2,15 \%, 64,03-65,11 \%, 34,40-34,99 \%$ y $49,90-$ $56,00 \%$, respectivamente. Entre los 181 cultivos puros de bacterias lácticas se identificaron Lactobacillus plantarum (40 cepas), Lactobacillus delbrueckii ssp. bulgaricus (35 cepas), Lactococcus lactis ssp. lactis biovar diacetylacti (22 cepas), Lactococcus lactis ssp. cremoris (18 cepas), Lactobacillus paracasei ssp. paracasei (10 cepas), Leuconostoc pseudomesenteroides (9 cepas) and Leuconostoc gelidum (12cepas) Enterococcus faecium (35 cepas). Asimismo, se detectaron levaduras en todas las muestras (55 cultivos puros). De estos, 40 se identificaron como Saccharomyces cerevisiae y 15 como Saccharomyces $\mathrm{sp}$.

PALABRAS-CLAVE: Bacterias lácticas - Leche de camella - Levadura - Mantequilla tradicional.

\section{SUMMARY}

Physicochemical and microbiological study of "shmen", a traditional butter made from camel milk in the Sahara (Algeria): isolation and identification of lactic acid bacteria and yeasts.

Microorganisms (aerobic bacteria, coliforms, lactic acid bacteria, psychrotrophs, lipolytic bacteria and yeasts) were isolated from 20 samples of shmen, a traditional clarified butter made from sour camel milk in the Algerian Sahara. The values of $\mathrm{pH}$, titratable acidity, $\mathrm{NaCl}$, total solid, moisture, and fat content ranged from : 3.11-4.97, 0.19$0.36 \%, 1.04-2.15 \%, 64.03-65.11 \%, 34.40-34.99 \%$, and 49.90-56\% respectively. A total of 181 isolates of lactic acid bacteria were identified as Lactobacillus plantarum (40 strains), Lactobacillus delbrueckii ssp. bulgaricus (35 strains), Lactococcus lactis ssp. lactis biovar diacetylacti (22 strains), Lactococcus lactis ssp. cremoris (18 strains), Lactobacillus paracasei ssp. paracasei (10 strains),
Leuconostoc pseudomesenteroides (9 strains) and Leuconostoc gelidum (12 strains) Enterococcus faecium (35 strains). Yeasts were isolated from all samples (55 isolates). Of these, 40 were identified as Saccharomyces cerevisiae and 15 isolates were identified as Saccharomyces sp.

KEY-WORDS: Camel milk - Lactic acid bacteria Traditional butter - Yeast.

\section{INTRODUCTION}

Indigenous dairy products made from different milk sources (cow, buffalo, sheep and goats) are traditionally produced and consumed in a majority of African and Arabian countries (Abd-El-Malek, 1987; El Marrakchi et al., 1988a, 1988b; Ashenafi, 1996; Gonfa et al., 1999; El Gendy, 2001; AbouDonia, 2002 and Ayad et al., 2004).

In the Algerian Sahara, there is a popular butter made from camel milk and is called shmen or semma (FAO, 1990). In this region, fresh camel milk is difficult to preserve because it usually contains a lot of impurities (sand, hair...) and rapidly becomes rancid. The Touaregs (nomad tribe of Sahara) improve its preservation quality by transforming it into a clarified butter (shmen). This product has played a major role in the diet of Touareg communities in the Sahara and today, there is a special demand for this product among consumers.

Shmen, can be preserved for up to one year depending on the moisture, humidity and room temperature of the storage place. This product is eaten as butter, used as oil for food preparation or for cooking, or also used as a hairdressing and as a skin cosmetic by both sexes. Also, shmen is used for roasting coffe beans in special Touareg traditional ceremonies.

In many regions of Sahara (Ain-Safra, Mograr, Bechar and Saida) (south-western Algeria), camel milk is fermented in a manner similar to that mentioned by Gast et al. (1969). The milk is stored in containers made of goat skin and allowed to ferment for 24 to 48 hours at room temperature. 
Churning is done when the container is half filled with sour milk. Some cold water is added into the goat skin before the end of churning in order to improve the firmness of the butter. It is then placed in a kettle and melted at $100^{\circ} \mathrm{C}$ for 30 minutes. A clarifying agent is added to hot butter and it is stirred with a wooden spoon. This agent can be crushed dates or a grated, roasted piece of ram horn, or also leaves of certain plants or seeds. Heating destroys most of the bacteria and the clarifying agent collects the dirt and floats to the top, where it can be skimmed off.

The mirobiological properties of butter made from different milks have been extensively studied by many researchers (Dwiedi and Kushwaha, 1972; Hankin and Hana, 1983; O'Mahony and Bekele, 1985; Ubach, 1986; Tasnim et al., 1993; O'Connor et al., 1993 and Zhao et al., 2000). Some researchers reported that lactococci, lactobacilli, enterococci, streptococci and leuconostocs were isolated from natural butters (Hukari and Rautavaara, 1972, Maret and Sozzi, 1976; Ozalp et al., 1980; Karahan, 1992 and Sagdic et al., 2002). Yeasts (especially S. cerevisiae) are commonly present in different traditional butters and are considered a secondary microflora (Benkerroum and Tamime, 2004).

Many Algerian studies have been carried out to isolate lactic acid bacteria from cow, sheep and goat's milk (Karam and Zadi, 1994; Karam, 1995, Kacem et al., 2003, and Kacem, 2005), camel's milk (Zadi Karam, 1998) or from traditional butter (Idoui, 1994 and Kacem, 2005). However, no information exists on indigenous lactic acid bacteria of shmen. The microflora may be affected by the chemical composition of camel milk, differences in traditional processing methods, packaging material and storage conditions. Therefore, the knowledge of bacterial microflora involved in butter fermentation is of prime importance in predicting and determining final shmen quality.

In this study, we aimed to know the biochemical and microbiological characteristics of shmen and to isolate lactic acid bacteria and yeasts from this traditional product.

\section{MATERIAL AND METHODS}

\subsection{Samples Collection}

Samples of shmen were obtained from the AinSafra (four samples), Mograr (five samples), Bechar (five samples) and Saida (six samples) Sahara regions in south-western Algeria. Thus, a total of 20 samples of shmen were aseptically taken and placed into sterilized bottles.

\subsection{Physicochemical analyses}

The $\mathrm{pH}$ of butter was determined electrometrically with a pH-meter (Micro pH 2002, Crison, Barcelona, Spain). Titratable acidity (as lactic acid) was measured as suggested by James (1995). Moisture and solid content were determined by heating the sample in an oven at $201^{\circ} \mathrm{C}$ until a constant weight was obtained (Anon. 1960). $\mathrm{NaCl}$ concentration was obtained using the method of the International Dairy Federation (Anon., 1969). The fat content was determined by the method of Anon. (1977). All analyses were performed in duplicate.

\subsection{Microbiological analyses}

Ten grams of butter sample were homogenized with $90 \mathrm{ml}$ of $0.85 \%(\mathrm{w} / \mathrm{v})$ sterile saline solution at $45^{\circ} \mathrm{C}$ for microbial analysis. Appropriate dilutions were spread-plated on the culture media indicated below.

Total lactic acid bacteria were enumerated in MRS agar (Merck, Darmstadt, Germany) (de Man et al., 1960) after $72 \mathrm{~h}$ at $30^{\circ} \mathrm{C}$. Lactobacilli were counted in MRS agar adjusted to $\mathrm{pH} 5.4$ with sodium acetate so that the growth of other organisms could be supressed (Garcia et al., 1987). Plates were incubated under anaerobic conditions (Gas Pak System, Becton Dickinson) at $30^{\circ} \mathrm{C}$ for 48 to $72 \mathrm{~h}$ until growth was observed. Lactococci were counted in M17 agar (Merck, Darmstadt, Germany) (Terzaghi \& Sandine, 1975) after incubation for $48 \mathrm{~h}$ at $30^{\circ} \mathrm{C}$. Total aerobic counts were made on plate count agar (Oxoid Ltd., UK) after incubation at $30^{\circ} \mathrm{C}$ for $72 \mathrm{~h}$, and coliform counts on violet red bile agar (Oxoid) after incubation at $30^{\circ} \mathrm{C}$ for $24 \mathrm{~h}$. Leuconostocs were enumerated on Sodium Azide Leuconostoc agar (SALA) (Merck, Darmstadt, Germany) (Harrigan and McCance, 1966) after incubation at $21^{\circ} \mathrm{C}$ for $72 \mathrm{~h}$. Enterococci were enumerated on citrate azide agar (CAA) (Merck, Darmstadt, Germany) after incubation at $37^{\circ} \mathrm{C}$ for $72 \mathrm{~h}$, yeasts on potato dextrose agar (PDA) (Oxoid) after incubation at $22^{\circ} \mathrm{C}$ for 5 days, psychrotrophs on plate count agar incubated at $7^{\circ} \mathrm{C}$ for 10 days, and lipolytic bacteria on tributyrin agar (Oxoid) after incubation at $30^{\circ} \mathrm{C}$ for $72 \mathrm{~h}$.

\subsection{Isolation and identification of lactic acid bacteria and yeasts}

\section{Lactic acid bacteria}

After bacterial counts, 10 colonies belonging to different types were randomly picked out from each 30-50 colony count plate of MRS, M17, Sodium Azide Leuconostoc agar or Citrate Azide agar and purified through three cycles of single colony cultures.

Lactobacillus plantarum ATCC 14917, Lactococcus lactis ATCC 11454, and Leuconostoc mesenteroides ATCC 23386 have been used as reference strains for lactic acid bacteria characterization and identification purposes.

Cell shape, cell arrangements, Gram-staining, catalyst ase activity $\left(3 \% \mathrm{H}_{2} \mathrm{O}_{2}\right)$, production of gas from glucose, temperature requirement $(15,40$ and $\left.45^{\circ} \mathrm{C}\right), \mathrm{NaCl}$ tolerance $(4,6.5,8$ and $10 \% \mathrm{NaCl})$ and 
growth at $\mathrm{pH} 3.9$ and 9.6 were performed in M17 or MRS broth. L-and D-lactic acid were analyzed enzymatically by the L-Lactic acid/D-Lactic acid kit (Roche diagnostic, Mannheim, Germany) according to the manufacturer's instructions. Homofermentative cocci which were capable of growing at 15 and $40^{\circ} \mathrm{C}$ but not at $45^{\circ} \mathrm{C}$ nor at $\mathrm{pH} 9.6$ were considered as lactococci according to the methods and criteria of Mundt (1986). Homofermentative cocci, grouped in pairs or short chains, which grew at 15,40 and $45^{\circ} \mathrm{C}$, survived after heating at $60^{\circ} \mathrm{C}$ after $30 \mathrm{~min}$, and grew at a pH 9.6 were considered as enterococci (Devriese et al., 1987). Heterofermentative cocci (leuconostoc) were identified according to Garvie (1986)

API 20 STREP (API-System, S.A., La Balme Les Grottes, Montalieu-Vercieu, France) was used for lactococci, enterococci and leuconostocs identification according to the manufacturer's instructions. Readings were done at $30^{\circ} \mathrm{C}$ after $48 \mathrm{~h}$.

Lactobacilli isolates were characterized according to the criteria of Kandler and Weiss (1986) and Schillinger and Lüke (1989). Arginine hydrolysis was tested in MRS broth containing $3 \mathrm{~g} / \mathrm{l}$ arginine and $2 \mathrm{~g} / \mathrm{l}$ sodium citrate replacing ammonium citrate. Ammonia was detected using Nessler's reagent. Acetoïn production was determined in MRS broth using the Voges-Proskauer test.

Lactobacilli isolates were tested for production of acids from carbohydrates and related compounds by using the API $50 \mathrm{CH}$ strips and API $50 \mathrm{CHL}$ medium (API-System, S.A., La Balme Les Grottes, MontalieuVercieu, France). The tests were done according to the manufacturer's instructions and the results were read after incubation at $37^{\circ} \mathrm{C}$ for $48 \mathrm{~h}$ and $72 \mathrm{~h}$. Identification of the isolates was done by the computerized database program provided by the manufacturer.

\section{Yeasts}

Yeasts were enumerated and the isolates distinguished separately according to their different morphological appearances upon growth in potato dextrose agar. Pure cultures of the yeast isolates were identified on the basis of the morphological and physiological criteria described by Kreger-van Rij (1984) as well as the criteria described by Barnett et al. (1990). The other biochemical tests were done with an API 20C AUX system (BioMerieux, S.A.) at $30^{\circ} \mathrm{C}$, and readings were made at 24, 48 and $72 \mathrm{~h}$.

Microorganisms were maintained in sterile reconstituted skim milk $(10 \% \mathrm{w} / \mathrm{v})$ at $4^{\circ} \mathrm{C}$ or at $-20^{\circ} \mathrm{C}$ in MRS broth supplemented with $20 \%$ glycerol. Working cultures were also kept on MRS agar, M17 agar or potato dextrose agar slants at $4^{\circ} \mathrm{C}$ and streaked every four weeks.

\section{RESULTS}

Table I shows the values of $\mathrm{pH}$, titratable acidity (TA), $\mathrm{NaCl}$, total solids (TS), moisture, and fat obtained from shmen. Samples collected from the Mograr region had the lowest $\mathrm{pH}$ values (3.11) while shmen from Bechar region had the highest (4.97). Samples collected from Ain-Safra region had the highest mean TA value $(0.36 \%)$ and the lowest mean TA was from samples collected from Saida $(0.20 \%)$. While mean salt content in shmen from Ain-Safra region was the highest (2.15\%), the samples from Mograr region had the lowest value (1.04\%). The total solid, moisture, and fat contents of shmen samples ranged from 64.03 and 65.11, 34.40 and 34.99 , and 49.90 and 56.20 in all regions, respectively.

Table II shows the counts of aerobic bacteria, coliforms, lactic acid bacteria, lactobacilli, lactococci, enterococci, yeasts, psychrotrophs and lipolytic bacteria recorded in shmen samples from the four regions of Algerian Sahara studied.

High counts of aerobic bacteria (mean log counts 2.76 to 3.88 ), lactic acid bacteria (mean log counts 3.8 to 3.96 ) and yeasts (mean log counts 2.08 to 3.88 ) were recorded in all samples. However low incidences of coliforms (mean log counts 0.90 to 1.66) as well as psychrotrophs (mean log counts 1.05 to 1.53 ) were detected. Lipolytic bacteria were detected in all samples (mean log counts 2.10 to 2.56).

Among lactic acid bacteria, 181 isolates were examined for identification. Table III shows the species of lactic acid bacteria and number of strains isolated from shmen. The lactic acid bacteria were identified as Lactococcus (40 isolates). They grew in $4 \% \mathrm{NaCl}$ but not in $6.5 \% \mathrm{NaCl}$ nor at $\mathrm{pH} 9.6$. All isolates grew at $15^{\circ} \mathrm{C}$ and $40^{\circ} \mathrm{C}$ but not at $45^{\circ} \mathrm{C}$.

Table I

Physicochemical characteristics of butter from camel milk (shmen)* collected in four regions of Algerian Sahara

\begin{tabular}{lcccccc}
\hline Region & pH & $\begin{array}{c}\text { Titratable } \\
\text { acidity (\%) }\end{array}$ & $\begin{array}{c}\text { NaCl } \\
(\%)\end{array}$ & $\begin{array}{c}\text { Total solid } \\
(\%)\end{array}$ & $\begin{array}{c}\text { Moisture } \\
\text { (\%) }\end{array}$ & $\begin{array}{c}\text { Fat } \\
(\%)\end{array}$ \\
\hline Ain-Safra & $4.87 \pm 0.23$ & $0.36 \pm 0.09$ & $2.15 \pm 0.03$ & $64.03 \pm 0.29$ & $34.44 \pm 0.55$ & $56.05 \pm 0.09$ \\
Mograr & $3.10 \pm 0.26$ & $0.22 \pm 0.07$ & $1.04 \pm 0.05$ & $65.00 \pm 0.22$ & $34.88 \pm 0.22$ & $58.13 \pm 0.03$ \\
Bechar & $4.97 \pm 032$ & $0.24 \pm 0.08$ & $1.32 \pm 0.06$ & $65.11 \pm 0.30$ & $34.99 \pm 0.33$ & $56.20 \pm 0.07$ \\
Saida & $4.38 \pm 0.33$ & $0.20 \pm 0.07$ & $1.15 \pm 0.07$ & $64.50 \pm 0.09$ & $34.40 \pm 0.66$ & $49.90 \pm 0.11$ \\
\hline
\end{tabular}

* Mean \pm standard deviation 
Table II

Mean log plate counts of different microbial groups of butter from camel milk (shmen)* collected in four regions of Algerian Sahara.

\begin{tabular}{lcccc}
\hline Microbial group & Ain-Safra & Mograr & Bechar & Saida \\
\hline Total aerobic count & $3.52 \pm 0.12$ & $2.76 \pm 0.19$ & $3.88 \pm 0.23$ & $3.54 \pm 0.19$ \\
Coliforms & $1.11 \pm 0.18$ & $1.03 \pm 0.20$ & $1.66 \pm 0.11$ & $0.90 \pm 0.15$ \\
Lactic acid bacteria & $3.80 \pm 0.13$ & $3.55 \pm 0.18$ & $3.96 \pm 0.15$ & $3.12 \pm 0.12$ \\
Lactobacilli & $2.30 \pm 0.16$ & $2.40 \pm 0.12$ & $2.62 \pm 0.13$ & $3.80 \pm 0.14$ \\
Lactococci & $1.90 \pm 0.15$ & $1.56 \pm 0.21$ & $1.98 \pm 0.14$ & $1.54 \pm 0.11$ \\
Enterococci & $2.69 \pm 0.11$ & $2.36 \pm 0.16$ & $1.55 \pm 0.17$ & $1.47 \pm 0.15$ \\
Yeasts & $3.88 \pm 0.19$ & $3.84 \pm 0.18$ & $2.98 \pm 0.18$ & $2.08 \pm 0.18$ \\
Psychrotrophs & $1.10 \pm 0.16$ & $1.05 \pm 0.15$ & $1.53 \pm 0.11$ & $124 \pm 0.17$ \\
Lipolytic & $2.13 \pm 0.13$ & $2.56 \pm 0.23$ & $2.42 \pm 0.16$ & $2.10 \pm 0.14$ \\
\hline
\end{tabular}

* Mean \pm standard deviation

They produced L-Lactic acid with no gas production in the presence of glucose. Of these, 22 isolates have the ability to hydrolyze arginine and 18 isolates to produce acetoîn. All of these characteristics, together with the API 20 STREP pattern of carbohydrate fermentation, identified the 22 isolates as L. lactis ssp. lactis biovar diacetylactis and the 18 isolates as $L$. lactis ssp. cremoris.

A total of 35 isolates obtained from Citrate Azide agar (CAA) were identified as Enterococcus. They did not produce gas from glucose fermentation, produced L-lactic acid, grew at 15,40 or $45^{\circ} \mathrm{C}$, survived at $60^{\circ} \mathrm{C}$ after 30 min., grew in $6.5 \%$ salt or at $\mathrm{pH}$ 9.6. Using API 20 STREP pattern of carbohydrate fermentation, the 35 isolates were identified as $E$. faecium.

Isolates picked from MRS agar were identified as Lactobacillus (85 isolates). They grew at $15^{\circ} \mathrm{C}$ but not at $45^{\circ} \mathrm{C}$ nor at $10 \% \mathrm{NaCl}$. They produced LLactic acid with no gas production from glucose and have the ability to hydrolyze arginine. All of these characteristics, together with the API $50 \mathrm{CH}$ pattern of carbohydrate fermentation, identified the isolates as L. plantarum (40 stains), L. delbrueckii ssp. bulgaricus (35 strains), and L. paracasei ssp. paracasei (10 strains).
Heterofermentative cocci (21 isolates) were identified as Ln. pseudomesenteroides (9 strains) and Ln. gelidum (12 strains).

A total of 55 isolates of yeasts were isolated from samples on potato dextrose agar plates. Of these, 40 were identified as belonging to the Saccharomyces because they reproduced by multilateral budding, formed pseudohyphae and asci containing one to four globose ascospores, fermented glucose, galactose and maltose, did not assimilate lactose and nitrate, and their cells were globose to subglobose or ellipsoidal to cylindrical. All of these characteristics, together with the API 20C AUX system (Bio Merieux, S.A.) pattern of biochemical tests, identified the 40 isolates as $S$. cerevisiae. The other 15 isolates were not identified as species level.

\section{DISCUSSION}

The results reported here constitute part of the study focusing on isolation and partial identification of lactic acid bacteria and yeasts from a food product hitherto not well examined: traditional butter (shmen) produced from camel milk in the Sahara regions

Table III

Species of lactic acid bacteria and number of strains isolated from shmen.

\begin{tabular}{lcc}
\hline Species & Number of isolates & (\%) \\
\hline L. lactis ssp. cremoris & 18 & 9.9 \\
L. lactis ssp. lactis biovar diacetylactis & 22 & 12.1 \\
E. faecium & 35 & 19.3 \\
L. plantarum & 40 & 22.1 \\
L. delbrueckii ssp. bulgaricus & 35 & 19.3 \\
L. paracasei ssp. paracasei & 10 & 5.5 \\
Ln. pseudomesenteroides & 9 & 4.9 \\
Ln. gelidum & 12 & 6.6 \\
\hline Total & $\mathbf{1 8 1}$ & $\mathbf{1 0 0}$ \\
\hline
\end{tabular}


(Algeria). The biochemical and microbiological characteristics of this butter are not documented. Therefore, our results are compared to those obtained with traditional fermented camel milk or with butter made from different milk type.

The physicochemical study of shmen indicated that, the values of $\mathrm{pH}$ varied in all samples (3.114.97). Similar results were reported in earlier studies on butters (Filkensen, 1987 and Sagdic et al., 2002). In all samples of shmen, the values of titratable acidity TA $(0.19-0.36 \%)$ were higher than values found by Bilgin (1996) and Hayaloglu (1999). On the other hand, the mean $\mathrm{NaCl}$ content (1.04 and $2.15 \%$ ) in all samples of butter was lower than the values found by El Sadek et al. (1975) and Hayaloglu (1999). In addition, the total solid, moisture, and fat contents, of shmen samples varied according to the samples of butter and regions. These results agreed with those obtained by Sagdic et al. (2002).

From the results, it is clear that lactic acid bacteria represented by L. lactis ssp. cremoris, L. lactis ssp. lactis biovar diacetylactis, E. faecium, L. plantarum, L. delbrueckii ssp. bulgaricus, L. paracasei ssp. paracasei, Ln. pseudomesenteroides and Ln. gelidum can be isolated from shmen. Yeasts were also routinely isolated and identified as $S$. cerevisiae or Saccharomyces sp.

L. plantarum (22.1\%), L. delbrueckii ssp. bulgaricus $(19.3 \%)$, E. faecium $(19.3 \%)$ and $S$. cerevisiae (63\%) were the major species of lactic acid bacteria and yeasts isolated from this product. Results on the species composition of the lactic microflora of shmen were similar to those reported by Sagdic et al. (2002) who isolated lactic acid bacteria from traditional butter represented essencially by strains of Ln. pseudomesenteroides and Ln. gelidum, L. delbrueckii ssp. bulgaricus and $E$. faecium. In the same study the isolation of $L$. lactis ssp. cremoris, L. lactis ssp. lactis biovar diacetylactis and L. plantarum was not reported. However, in previous studies (Idoui, 1994; Benkerroum and Tamine, 2004; and Kacem, 2005), L. plantarum as well as the other mesophilic lactobacilli have been frequently reported to be the dominant microorganisms among the non-starter lactic acid bacteria in long ripening butters or cheeses due to their unique ability to grow in highly hostile environments and to possessing of a wide range of hydrolytic enzymes, including lipases and proteases (Wouters et al., 2002). Therefore, it is not surprising that these bacteria would be dominant and one of the responsible agents for the maturation of shmen.

Enterococci represent an important part of the bacterial microflora of shmen: mean log plate counts of enterococci in different samples range from 1.47 to 2.69 (Table II) and a total of $35 E$. faecium strains were isolated (Table III). This group of bacteria play a major role in the ripening and aroma development in butter and many types of traditional cheeses (Centeno et al., 1996). In addition, E. faecium was selected together with other lactic acid bacteria for use in starter culture preparation (Coppola et al., 1988 and Parente et al., 1989). A food company sought clearance from the British "Advisory Committee on Novel Foods and Processes" (ACNFP) for the use of E. faecium strains as a starter culture in fermented dairy products (ACNFP, 1996), and the Committee decided that the culture was acceptable for such use. Clearly, the enterococci play an important role in the manufacturing of butters typical to some regions, and their use has a major impact on this part of artisan dairy products.

L. delbrueckii ssp. bulgaricus was found in all butter samples; this microorganism represented $19.3 \%$ of the isolates. Similar results were reported by Dave and Shah (1997). E. faecium species was also isolated in this study. This genus has been isolated from butters (Hukari and Rautavaara, 1972; Ozalp et al., 1980 and Sagdic et al., 2002) and isolates have been identified, characterized and utilized as starter cultures. Other bacteria such as Ln. pseudomesenteroides and L. lactis ssp. lactis biovar diacetylactis were also found in shmen. Generally, the conventional method for obtaining butter involves the ripening of cream through the addition of a starter culture mixture containing $L$. lactis ssp. lactis biovar diacetylactis and $L n$. pseudomesenteroides to produce sufficient quantities of lactic acid to reduce the $\mathrm{pH}$ to around 4.6 to 4.4 (Kornacki and Flowers, 1998). Also, L. lactis ssp. lactis biovar diacetylactis strains produce a sufficient quantity of diacetyl which is the major flavoring component and antimicrobial property of cultured butter (Schieberle et al., 1993). Probably, the presence of this type of bacteria was responsible for the pleasant taste and smell of shmen.

On the other hand, analysis of shmen showed that mean log counts of yeast exceeded 3.88. Their high counts and well-known high lipolytic activity suggest that they may play an active role in shmen ripening

\section{CONCLUSION}

The results of this study indicate that the natural Algerian butter from camel milk revealed a diversity of microflora. This diversity could be linked to the quality of camel milk (composition of milk during lactation period), $\mathrm{pH}$, moisture, humidity, room temperature of the manufacturing place, etc.

"Shmen" samples from four regions were characterized by low incidences of opportunistic bacteria, including coliforms, psychrotrophs and lipolytic bacteria. This is important for some algerian populations who live in the Sahara. In addition, different species of lactic acid bacteria and yeasts present in this product were isolated and identified. Probably, more emphasis should be placed in our laboratory on the role of lactic acid bacteria and yeasts, which have not been fully investigated in shmen so far. We think this type of study will 
contribute to standardize the production methods of butter from camel milk and to improve its safety.

\section{ACKNOWLEDGEMENTS}

This study was supported by a grant of the "Ministère de l'Enseignement Supérieur" of Algeria (Project: F3101/04/97) and a grant of ANDRS (Project: 02/12/01/99038).

\section{REFERENCES}

Abd-El-Malek, Y. 1987. Traditional Egyptian dairy fermentations. In Stantan, W.R., Da Silva, E. J. (Eds), Global impact of food Microbiology (GIAM)- State of the Art: GIAM and Relevalence to Development in Developing Contries. University of Malaya Press, Kuala Lumpur, pp. 198-208.

Abou-Donia S. A. 2002. Recent development in Ras cheese research: a review. Egypt. J. Dairy Sci, 30, 155-166.

ACNFP. 1996) Report on Enterococcus faecium strain K77D. MAFF Advisory Committee on Novel Foods and Processes, Report, Ergon House c/o Nobel House, 17 Smith Square, London SW1 3JR, UK.

Anonymous (1960). Determination of moisture content butter. Fil-IDF Standard 10, Brussels.

Anonymous. 1969. Determination of salt (Sodium Chloride) content butter. Fil-IDF Standard 12A, Brussels.

Anonymous (1977). Butter production of water, solid-nonfat and fat contents on the same test portion. Fil-IDF Standard 80, Brussels.

Ashenafi M. 1996. Effect of container smoking and incubation temperature on the microbiological and some biochemical qualities of fermenting Ergo, a traditional Ethiopian sour milk. Int. Dairy.J. 6, 96-104.

Ayad E. H. E., Nashat S., El-Sadek N., Metwaly H., ElSoda M. 2004. Selection of wild lactic acid bacteria isolated from traditional Egyptian dairy products according to production and technological criteria. Food Microbiol, 21, 715-725.

Barnett J. A., Payne R. W., Yarrow D. 1990.. Yeasts: characteristics and identification. C. U. Press Syndicate of the University of Cambridge, Cambridge.

Benkerroum, N., Tamime A. Y. 2004). Technology transfer of some Moroccan traditional dairy products (Iben, jben and smen) to small industrial scale., Food Microbiol. 65, 1-15.

Bilgin B. 1996) A research on the determination of some sensory, physical, chemical and microbiological properties during the storage period of butter produced by souring with sweet and four different culture combinaisons. Ph. D. Thesis Trakya University, Tekirdag-Turkey.

Centeno J. A., Menéndez S., Rodriguez-Otero J. L 1996. Main microbial flora present as natural starters in Cebreiro raw cow's-milk cheese (Northwest Spain). Int. Food Microbiol. 33, 307-313.

Coppola S., Parente E., Dumontet S., La Peccerella A. 1988. The microflora of natural whey cultures utilized as starters in the manufacture of Mozzarella cheese from water-buffalo milk. Lait. 68, 295-310.

Dave R. I., Shah N. P. 1997. Viability of yoghurt and probiotic bacteria in yoghurt made from commercial starter cultures. Int. Dairy J. 7, 31-41.
De Man, J.C., Rogosa, M., Sharpe E.M. 1960. A medium for the cultivation of lactobacilli. J. Appl. Bacteriol. 23, 130-135.

Devriese L. A., Van de Kerckhove A., Kilpper-Bälz, R., Schleifer K. H. 1987. Characterization and identification of Enterococcus species isolated from the intestines of animals. Int. J. Syst. Bacteriol. 37, 257-259

Dwiedi H. B., Kushwaha S. 1972. A note on the microflora of Desi butter. Indian. J. Anim. Sci. 42, 193-198.

El Gendy S. M. 2001. Some traditional fermented dairy products in Egypt. Proceeding $f$ the Eighth Egyptian conference for Dairy Science and Technology, Cairo, Egypt, November 3-5, Egypt, J. Dairy Sci. 465-479.

El Marrakchi A., Tantaoui-Elaraki A. El Mane A.,Tifrit L. 1988a. La flore microbienne du smen marocains. I, Flore naturelle et flore d'intérêt hygiénique. Le Lait. 68, 205-218.

El Marrakchi, A., Tantaoui-Elaraki A., Hamama A., Grini A. 1988b. La flore microbienne du smen marocains. II, Flores lipolytique et casènolyque. Le Lait. 68, 333348.

El Sadek G. M., Teama Z. Y., Khalafalla S. M., Sultan N. E. 1975. Compositional properties of market butter in Egypt. Milchwissenschaft, 30, 354-356.

FAO. 1990. Importance, technology and economics of traditional milk products. In: FAO Publications Division, Food and Agriculture Organization of the United Nations, Via delle Terme di Caracalla, 00100 Rome, Italy.

Filkensen W. E. 1987. Production proportions and product quality. Nordisk Mejeriindustr 14, 414-416.

Garcia, M. C., Oteco A., Garcia M. L., Moreno B. 1987. Microbiological quality and composition of two types of Spanish sheep's milk cheeses (Manchego and Burgos varieties). J. Dairy Res. 54, 551-557.

Garvie E. I. 1986. Genus Leuconostoc. In : Bergey's Manual of Systematic Bacteriology, 9th edn (Eds P. H.A. Sneath, N.S. Mair, M.E. Sharp, J.G. Holt). The Williams \& Wilkins Company, Baltimore MD, USA. pp. 1071-1075.

Gast M., Mauboisj, L., Adda, J. 1969. Le lait et les produits laitiers en Ahaggar. Centre Rech. Anthr. Prehist. Ethn.

Gonfa A. Fite A., Urga K., Gashe B. A. 1999. The microbiological aspects of ergo (ititu) fermentation. SINET: Ethiop. J. Sci. 22, 2-6.

Gonfa A., Foeter H. A, Holzapfel W. H. 2001. Field survey and literature review on traditional fermented milk products of Ethiopia. Int. J. Food Microbiol. 68, 173186.

Hankin L., Hanna J. G. 1983. Quality of butter and blends of butter with oleomargarine. Dairy Food Sanitation 3, 458-460.

Harrigan W. F, McCance M. E. 1966. Laboratory Methods in Microbiology, p. 362, London and New York, Academic press.

Hayaloglu A. A. 1999. A comparative study on physicochemical, microbiological and organoleptic qualities of butter produced from cream and yoghurt in Malatya region M. Sc. Thesis p. 74, Cukurova University, Istitute of Natural and Applied Sciences, Adana, Turkey.

Hukari I., Rautavaara K. 1972. Enterococci as indicators of microbiological quality of butter. Karjantuote 55, 5657.

Idoui T. 1994. Purification, caractérisation et identification de souches de bactéries lactiques isolées du beurre traditionnel local (Jijel). Etude de quelques aptitudes 
technologiques, inhibitions interbactériennes. Reconstitution de levains lactiques mésophiles.» Thèse, d'Ingenieur d'Etat en Science Agronomique Option : Technologie Alimentaire et Nutrition), I'INFSA, Mostaganem, pp. 1-123.

James C. S. 1995. Analytical Chemestry of Food. Oxford, Chapman \& Hall

Kacem M. 2005. Bactéries lactiques d'Algérie: Isolement, identification et caractéristiques technologiques. Bactériocines produites par Lactococcus lactis et Lactobacillus plantarum. Thèse de Doctorat d'état $p$. 281, Université d'Oran.

Kacem M., Zadi-Karam H., Karam N.E.(2003. Identification of lactic acid bacteria isolated from milk and olive oil in western Algeria. Actes Inst. Agrono. Vet. (Maroc) 23, 135-141.

Kandler, O., Weiss, N. 1986. Regular, nonsporing Gram positive rods. Genus Lactobacillus. In Bergey's Manual of Systematic Bacteriology, Vol. 2, Edited by P. H.A. Sneath, N.S. Mair, M.E. Sharp, J.G. Holt,. The Williams \& Wilkins Company, Baltimore MD, USA. pp. 1208-1234.

Karahan A. G. 1992. Obtaining high level diacetyl producer mutants from Streptococcus diacetylactis and determination their phage sensitivity vs wild strains, Ph.D. Thesis, p. 118, Ankara University, Graduate School of Natural, and Applied Sciences, Ankara, Turkey.

Karam N., Zadi-Karam H. 1994 Isolement et caractérisation de bactéries lactiques de laits crus d'Algérie. In Alimentation, Génétique et Santé de L'enfant, Eds. J. F. Desjeux et M. Touhami, L'Ht. pp. 257-264.

Karam, N. 1995. Constitution d'un souchier de bactéries lactiques à intérêt biotechnologique: Etude Biochimique et Moléculaire. Thèse de Doctorat d'état p. 212, Université d'Oran.

Kornacki J. L., R. S. Flowers 1998. Microbiology of butter and related products. In Appl. Dairy Microbiol., New York, Marcel Dekker Inc. pp. 325-331.

Kreger-van Rij N. J. W. 1984. Yeasts". Third revised and enlarged edition, Elsevier Science Publishers Amsterdam.

Maret R., Sozzi T. (976. Lactic flora in Swiss Alpine cheesemaking. Lait 56, 304-318.

Mundt, J. O. 1986. Lactic acid streptococci. in Bergey's Manual of Systematic Bacteriology, Vol. 2, (Eds, PHA
Sneath, N. S. Mair and M. E. Sharp, J. G. Holt). The Williams \& Wilkins Company, Baltimore MD, USA. pp. 1264-1251.

O’Connor C. B., Mezgebu S., Zewde Z. 1993. Improving the efficiency of butter making in Ethiopia. FAO World Anim. Rev., 50-53.

O'Mahony F., Bekele E. 1985. Traditional butter making in Ethiopia and possible improvements. ILCA Bull. 22, 914.

Ozalp E., Tekinsen O. C. Ozalp G., hamzaçebi Y. 1980. Studies on the preparation of the Turkish butter starters. Research Fund of Veterinarian Medicine, Project Number 322, Turkey.

Parente E., Villani F., Coppola R., Coppola S. 1989. A multiple strain starter for water-buffalo Mozzarella cheese manufacture. Lait 69, 271-279.

Sagdic O. Arici M, Simsek O. 2002. Selection of starters for traditional Turkish yayik butter made from yoghurt. Food Microbiol., 19, 303-312.

Schieberle, P., K. Gassenmeier, H. Guth, A. S., Grosch W. 1993. Character impact odor componds of different kinds of butter. Lebensm. Wiss. Technol., 26, 347-356.

Schillinger, U., Lücke F.K. 1989. antibacterial activity of Lb. sake isolated from meat. Appl. Environ. Microbiol., 55, 1901-1906.

Tasnim K, Khalid R., Yaqub C. M. 1993. Microbiological status of different varieties of butter. Sci. Int. 5, 81-83.

Terzaghi, B. E., Sandine W. E. 1975. Improved medium for lactic streptococci and their bacteriophages. J. Appl. Bacteriol. 29, 807-813.

Ubach T. H. 1986. Microbiological qualitiy of Spanish butter and margarines. Ann. Bromatol. 37, 307-313.

Wouters J. T. M., Ayad E. H. E., Hugenholtz J., Smith G. 2002. Microbes from raw milk for fermented dairy products. Int. Dairy J. 12, 91-109.

Zadi-Karam H. 1998. Bactéries lactiques isolées de lait de Camelus dromedarius: Etude microbiologique et biochimique, Caractéristiques technologiques, Elaboration de ferments lactiques mésophiles et fabrication de fromages. Thèse de Doctorat d'Etat. Université de Constantine, Algérie, pp. 205.

Zhao T. Doyle M. P. and Berg D. E. 2000. Fate of Campylobacter jejuni in butter. J. Food Prot. 63, 120122.

Recibido: Mayo 2005 Aceptado: Noviembre 2005 